\title{
Dry Phosphorus silicate glass etching and surface conditioning and cleaning for multi-crystalline silicon solar cell processing
}

\author{
Ahmed S. Kagilik \\ Faculty of Engineering-Sabratah, Al-Zawia University \\ Al-Zawia - Libya \\ e-mail: as.kagilik@gmail.com
}

الملخص: بِ هذا البحث تم تطبيق تقنيت التنميث الجاف لطبقت سيليكات الفوسفور الزجاجيت (PSG)، كطريقت بديلت

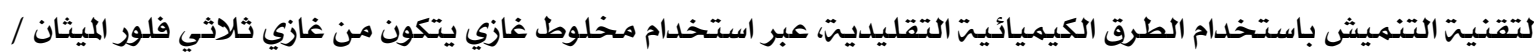

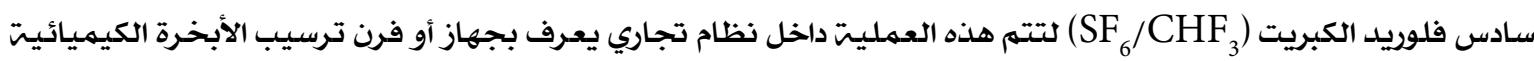
المعززة باستخدام تقنيات بلازما نيترات السيليكون (CHECVD_SiN). وهِّ هذا العمل تم بحث مدى اعتماديت أداء الخليت الشمسيت على درجت حرارة التنميش داخل الفرن ليتم بالتالي الاختيار

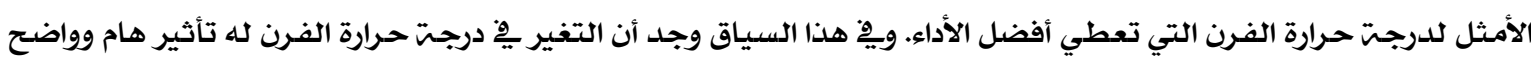
على كافت معلميات الخليت الشمسسيتة. وبعد الانتهاء من عمليتت التنميث الجـاف لطبقت سيليكات الفوسفور الزجاجيت فقد تم بحث وتطوير عمليت لاحقت ضمن مـراحل تصنيع الخليت الشمسيت السيليكونيت والتي تتمثل مباثرة يِّ عمليت المعالجت والتنظيف السطحي للخليت باستخدام تقنيت البـلازما. فعمليتت المعالجت السطحيت للخليت الشهسيت تستخدم لتحويل أو إزالت طبقت البوليمـر التي تترسب على سطح الخليتة أثناء مـرحلتة إزالت طبقت سيليكات الفوسفور الزجاجيتة. ويٌ هذا السياق استخدم لهذا الغرض غازا الأكسجـين والهيدروجـين لنجد أنه بعد تطبيق هذه المرحلت فإن طبقت البوليهـر قد تم ازالتها أو تقليلها إلى الحد الأدنى. وقد تم بحث مدى تأثر أداء الخليت الشهسيت بظروف عمليت التنظيف البـلازميتة، حيث وجد أنه بعد أن تم الاختيار الأمثل

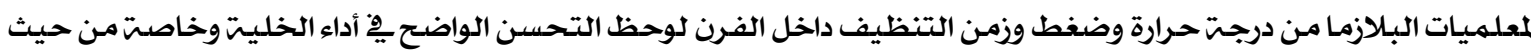
الزيادة والكسب الحاصل ِِ كفاءة الخليت الشمسيت والتي تصل إلى نسبت زيادة تقدر بحوالي 0.6 \% مقارنت مـ كفاءة الخليت عند علدم تطبيق هذه المرحلتة من التصنيع. ومن ناحيت أخرى فقد وجد أن خصائص الخليت الشهسيت بعد إجـراء أو تطبيق هذه التقنيت يمكن أن تصل إلى نفس أداء وخصائص الخليت الشهسيت التي يتهم تصنيعها بالطرق التقليديت التي تتمثل ِِّ إزالت طبقت سيليكات الفوسفور الزجاجيت باستخدام الطرق الكيميائيت التقليديت (الغطس ِِّ محلول حامض الهيدروفلوريك المخفف) وهو ما يبرهن على مدى جدوى وفعاليت المعالجت الجافت لتنظيف سطح الخليت الشهسيت باستخدام غازي الأكستجين والهيدروجـين وبتقنيت البـلازما وخاصت إذا ما أخد العامل البيئي يِ الاعتبار.

Abstract: As an alternative to the wet chemical etching method, dry chemical etching processes for Phosphorus silicate glass (PSG) layer removal using Trifluormethane /Sulfur Hexafluoride $\left(\mathrm{CHF}_{3} / \mathrm{SF}_{6}\right)$ gas mixture in commercial silicon-nitride plasma enhanced 
chemical vapour deposition (SiN-PECVD) system is applied. The dependence of the solar cell performance on the etching temperature is investigated and optimized. It is found that the SiN-PECVD system temperature variation has a significant impact on the whole solar cell characteristics. A dry plasma cleaning treatment of the Si wafer surface after the PSG removal step is also investigated and developed. The cleaning step is used to remove the polymer film which is formed during the PSG etching using both oxygen and hydrogen gases. By applying an additional cleaning step, the polymer film deposited on the silicon wafer surface after PSG etching is eliminated. The effect of different plasma cleaning conditions on solar cell performance is investigated. After optimization of the plasma operating conditions, the performance of the solar cell is improved and the overall gain in efficiency of $0.6 \%$ absolute is yielded compared to a cell without any further cleaning step. On the other hand, the best solar cell characteristics can reach values close to that achieved by the conventional wet chemical etching processes demonstrating the effectiveness of the additional $\mathrm{O}_{2} / \mathrm{H}_{2}$ post cleaning treatment.

Keywords: Solar Cells, crystalline silicon, PSG, Plasma etching.

\section{INTRODUCTION}

The rapid growth of the photovoltaic market is still dominated by searching for high solar cell efficiencies with cost effective technologies. Therefore, the development of high performance solar cells using cheap semiconductor materials and new processing techniques can have a significant impact on the cost reduction. Due to the relatively low production cost and good material performance, the share of multi-crystalline silicon (mc-Si) solar cells reaches more than $40 \%$ of the PV production capacity and their use is still steadily increasing [1]. Recently, the main task of the solar cell industry is to increase the cell throughput by reducing the silicon starting material or evaluating new processing techniques which improve the solar cell efficiencies. The widely accepted approach to reduce the cost of the silicon substrate material while maintains high efficiency is to use large and thin wafers. On the other hand, decreasing of DI water consumption as well as the expensive and hazards chemicals can play a significant role in reducing the processing costs [2].

Wet chemical processing of high efficiency silicon solar cells is still applied for many fabrication steps like wafer surface texturing and cleaning, saw damage etching and phosphorous silicate glass (PSG) etching, etc. Due to increasing water costs and using harmful acids like hydrofluoric acid (HF) replacement by dry processing technique, which is characterized by low costs of water consumption and chemical waste disposal, is mandatory.

Dry plasma processing is considered as the most promising and cost-effective approach for solar cell fabrication technique. This technology can offer the possibility for higher cell efficiencies at low processing costs due to several advantages compared to 
wet chemical fabrication steps such as $[2,3]$ :

- Different processing steps can be combined in one vacuum system.

- Full control of all processing parameters.

- Suitability for high throughput processing.

- Compatible with using thinner substrate materials.

- Suitable for strictly one-sided treatment and conditioning.

- Handling of less harmful acids like HF.

- Low water consumption.

Today, dry chemical processing of high efficiency silicon solar cells is applied for many fabrication steps like, wafer surface cleaning [4], texturing [5], emitter etching back [6, 7] and PSG etching [8], etc., but is still limited as commercial technology in solar cells industry.

Phosphorus silicate glass (PSG) etching represents the most significant applications of dry plasma etching. The PSG layer is created during emitter diffusion and this layer has to be removed prior to the SiN layer deposition step. For this purpose, instead of using HF dip as conventional method, a plasma etching technique is applied for removing this layer, demonstrating that dry PSG etching of mc-Si solar cells can achieve nearly similar performance compared to the wet chemically etched references. $\mathrm{CHF}_{3} / \mathrm{SF}_{6}$ (Trifluormethane / Sulfur Hexafluoride) gas mixture is employed to remove the PSG layer from the silicon surface providing a high selectivity ratio between PSG and the underlying Si emitter [9].

Due to the carbon contained in $\mathrm{CHF}_{3}$ gas, a thin hydrocarbon and/or fluorocarbon film of a few nanometers is formed on the silicon wafer surface during the PSG etching, which has an effect on the silicon etch rate and hence the selectivity between the $\mathrm{SiO}_{2}$ or PSG and silicon. On the other hand, the presence of this polymer layer causes a small loss in the open circuit voltage and fill factor of the solar cell [10]. Further improvement of the solar cell performance can be expected if this layer is removed prior to further cell processing. This can be implemented by an additional surface cleaning treatment of the silicon wafers in oxygen gas plasma (ashing) $[10,11]$. Therefore, after optimization of the plasma parameters for PSG etching and before the PECVD SiN antireflection coating (ARC) layer deposition, an additional dry plasma treatment step is conducted to clean the wafer surface and remove the created hydrocarbon layer deposited during dry PSG etching.

The aim of this work is the development and implementation of plasma etching processes for solar cell fabrication. In this direction, we applied the plasma etching, instead of wet chemical etching technique, to remove the PSG layer using $\mathrm{CHF}_{3} / \mathrm{SF}_{6}$ gas mixture in a SiN-PECVD system. After optimization of the plasma parameters for PSG etching, an additional conditioning of the wafer surface is conducted and a detailed investigation to optimize the dry cleaning process in order to achieve a high solar cell performance is performed. For cleaning purposes, the oxygen and hydrogen gases are used and the process is based on a plasma 
oxygen cleaning directly followed by few minutes of cleaning with the hydrogen gas.

\section{EXPERIMENTAL}

A set of p-type neighboring multicrystalline silicon wafers (Baysix 125x125 $\mathrm{mm}^{2}$ ) is used in this work. The resistivity range is $0.5-2.0 \Omega-\mathrm{cm}$ and the wafer thickness is of about $270 \mu \mathrm{m}$. The saw damage of the wafers is removed in alkaline solution followed by cleaning in a hot nitric acid $\left(\mathrm{HNO}_{3}\right)$. The phosphorous emitter diffusion is accomplished in a quartz tube

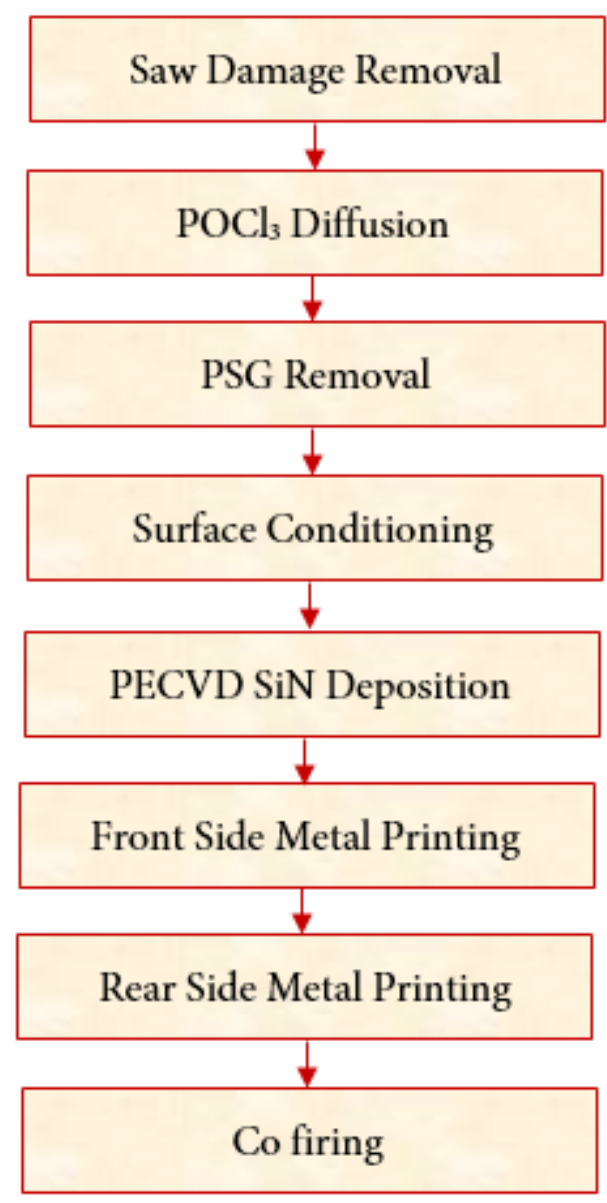

Figure (1). Applied process sequence for multi-crystalline silicon material

furnace using $\mathrm{POCl}_{3}$ liquid source resulting in a homogeneous emitter with a sheet resistance of $55 \Omega / \square$. After removing the phosphorous glass, a silicon nitride $\left(\mathrm{SiN}_{\mathrm{x}}\right)$ layer was deposited as antireflection coating (ARC) and surface passivation layer in a commercial Centrotherm PECVD reactor. Finally, the solar cells are screen printed with silver and aluminum pastes on the front and back sides, respectively. The contacts are cofired through the $\mathrm{SiN}_{\mathrm{x}}$ layer using a belt line furnace. The corresponding standard solar cell processing steps are shown in Figure 1.

The phosphorous silicate glass is conventionally removed by HF etching. In this work, the wet chemical method is replaced by a plasma dry etching technique. For this purpose, we use $\mathrm{CHF}_{3}$ and $\mathrm{SF}_{6}$ as etching gases. Before the $\operatorname{SiN}_{x}$ deposition step, an additional $\mathrm{O}_{2} / \mathrm{H}_{2}$ plasma cleaning treatment is applied to remove the created hydrocarbon layer deposited during dry PSG etching. These dry processing steps are carried out in the same $\mathrm{SiN}_{\mathrm{x}}$-PECVD system.

\section{RESULTS AND DISCUSSION}

\subsection{Dry phosphorus silicate glass removal}

Phosphorus silicate glass (PSG) etching represents the most significant applications of dry plasma etching. The PSG layer is created during emitter diffusion and this layer has to be removed prior to the $\mathrm{SiN}$ layer deposition step. Conventional solar cell fabrication applies wet chemistry for etching this phosphorus glass layer by using a toxic hydrofluoric acid. It has been demonstrated that dry plasma etching is a suitable process for the removal of the PSG layer and can be used instead of a wet chemical etching process. For PSG etching, 
one of the most important requirements is to achieve a high selectivity between the PSG layer and the Si underlying emitter. For this purpose, $\mathrm{CHF}_{3} / \mathrm{SF}_{6}$ gas mixture is employed to remove the PSG layer from the silicon surface providing a high selectivity ratio between PSG and the underlying Si emitter with efficiencies for mc-Si solar cells close to that obtained by a conventional wet chemical etching process [10].

In this work, we applied the plasma etching to remove the PSG layer using $\mathrm{CHF}_{3} / \mathrm{SF}_{6}$ gas mixture in a SiN-PECVD system and a detailed investigation is performed to optimize the dry PSG etching process in order to achieve a high solar cell performance. The effect of plasma etching on the wafer surface homogeneity after PSG removal is investigated by measuring the sheet resistance of the wafer surface before and after plasma treatment using a fourpoint probe technique. The process was applied on many samples etched at the same time and placed on various boat positions. The results obtained from the experiment show high sheet resistance homogeneity for all tested samples, yielding a sheet resistance range of about $55 \Omega / \square$ with a Standard deviation $<2 \Omega / \square$ throughout the whole wafer surface, as shown in Figure 2.

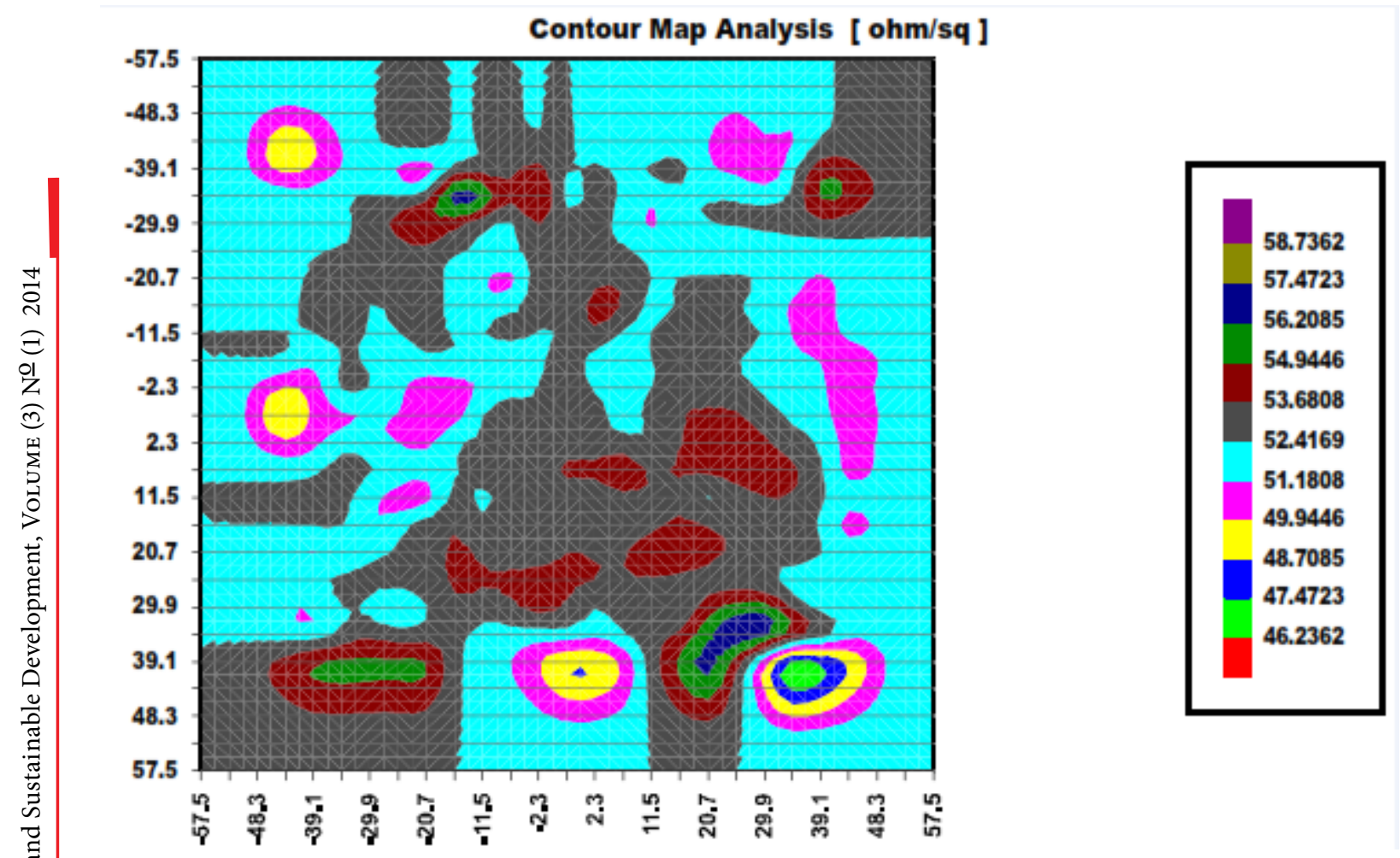

Figure (2). Sheet resistance distribution proving the etch homogeneity on the whole wafer surface.

During the PSG etching all the plasma pressure, plasma duration and etching time) parameters (gases flow, plasma power, are varied and optimized. It is found that 
the solar cell characteristics are strongly depending on these parameters. In this paper, only the temperature effect on the solar cell performance is described. For this experiment, the tube temperature is independently controlled and is varied between 100 and $400{ }^{\circ} \mathrm{C}$ while the other plasma parameters are held constant during the PSG etching.

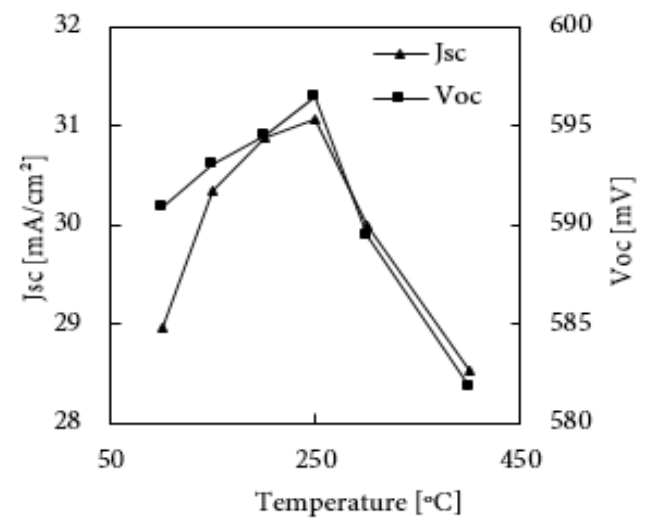

Figure (3). $\mathrm{J}_{\mathrm{sc}}$ and $\mathrm{V}_{\mathrm{oc}}$ of the solar cell measured at different tube temperatures.

Figure 3 shows the relation between the tube temperature and the open circuit voltage $\left(\mathrm{V}_{\mathrm{oc}}\right)$ and short circuit current $\left(\mathrm{J}_{\mathrm{sc}}\right)$ of the solar cell, while Figure 4 shows the effect of the tube temperature on the solar cell efficiency $(\eta)$ and fill factor (F.F.). As can be seen, the temperature variation has a significant impact on the whole solar cell characteristics. The solar cell efficiency increases as the temperature is increasing from $100^{\circ} \mathrm{C}$ until the efficiency reaches the maximum value at $250{ }^{\circ} \mathrm{C}$. By further increasing the temperature, the cell efficiency decreases more rapidly. This can be explained by two phenomena: (i) at low temperature values, the etch rate is very low and no etching step is excited. (ii) At high etching temperatures, a thick polymer layer is deposited on the silicon wafer surface that limits the cell efficiency. This will be described in the next section. The other solar parameters $\left(\mathrm{J}_{\mathrm{sc}}, \mathrm{V}_{\mathrm{oc}}\right.$ and fill factor) show the same dependency on the tube temperature as the solar cell efficiency, as shown in the figures.

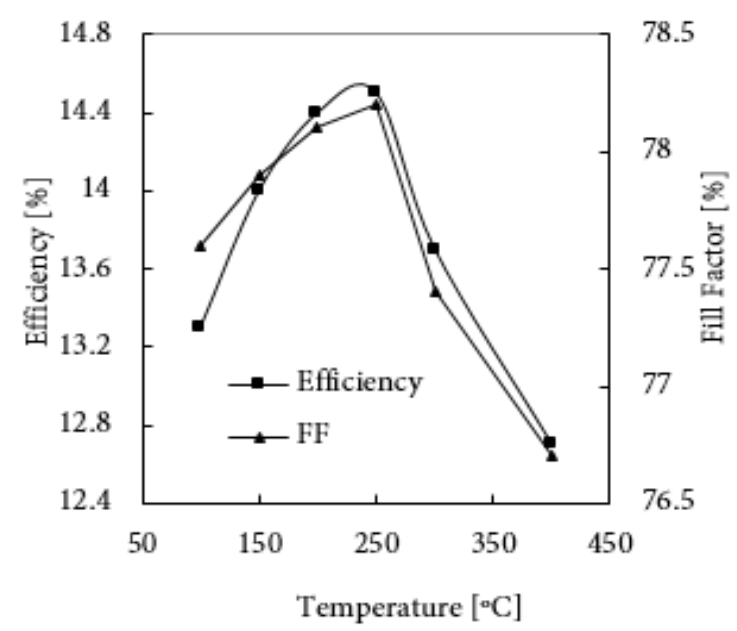

Figure (4). Effect of tube temperature on solar cell efficiency and fill factor.

\subsection{Dry plasma surface conditioning and cleaning}

To demonstrate the effectiveness of the post cleaning treatment of the wafer surface after the PSG etching, different plasma cleaning methods are tested by using single and mixture of oxygen and hydrogen gases. It has been found that the best solar cell performance is obtained when the extra cleaning step is implemented using plasma oxygen cleaning directly followed by few minutes of cleaning with the hydrogen gas $\left(\mathrm{O}_{2} / \mathrm{H}_{2}\right.$ plasma clean $)$ as shown in Figures 5 and 6 . These results show that an extra $\mathrm{O}_{2} / \mathrm{H}_{2}$ cleaning step can improve the solar cell performance due to the removal 
of the hydrocarbon and/or fluorocarbon composition from the wafer surface compared to the other cleaning steps. The lowest solar cell efficiency values are obtained when only PSG etching is applied without any additional surface cleaning treatment [12].

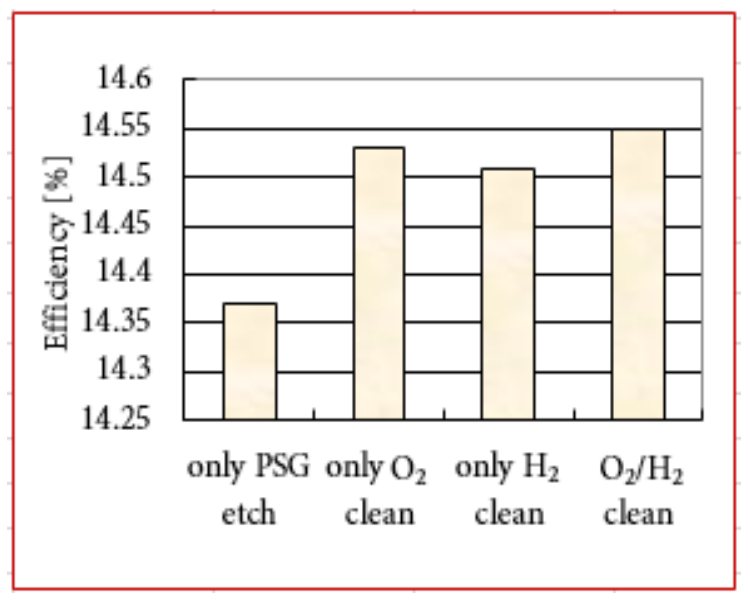

Figure (5). Measured solar cell efficiency with different plasma cleaning steps.

The influence of the dry cleaning processing step on composition of residues created on $\mathrm{Si}$ wafer surface during PSG etching is analysed by measuring the chemical profile of the etched silicon wafer surface using the time-of-flight secondary ion mass spectroscopy (TOF-SIMS). In this technique, positive ions sputtered from 60x60 $\mu \mathrm{m}$ sample surface by a $25 \mathrm{kV}$ Ga source are detected and the spectra over a period of $100 \mu$ s are taken then the compositions of the residues formed on the sample surface are analyzed. The composition of the hydrocarbon compounds is detected for three etched samples (A, B and C). Dry plasma etching technique is applied on the first sample by using $\mathrm{CHF}_{3} / \mathrm{SF}_{6}$ mixture gases to remove the PSG layer. An extra post cleaning step is applied on the second sample using dry $\mathrm{O}_{2} / \mathrm{H}_{2}$ plasma cleaning after dry PSG etching. HF dip method (wet chemical etching) is used for the third sample to remove the PSG layer and is considered as a reference. Figure 7 shows the composition of hydrocarbon films deposited on the Si wafer surfaces after dry and wet etching processes. As can be seen, high concentration of the hydrocarbon compounds is observed for sample (A), indicating that the surface is contaminated. Furthermore, high intensity of carbon and phosphorous signals are detected, while the Si signal is strongly suppressed for this sample. For etched samples B and C, the hydrocarbon components concentration is decreased during an extra dry plasma $\mathrm{O}_{2} / \mathrm{H}_{2}$ cleaning or PSG etched off in HF respectively. On the other hand, the Si signal is dominant for these samples, as shown in the figures.

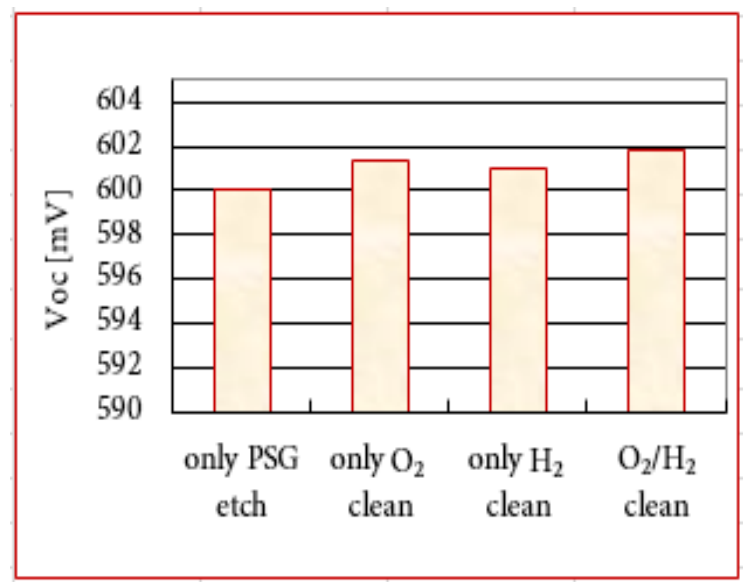

Figure (6). Measured open circuit voltage with different plasma cleaning steps. 

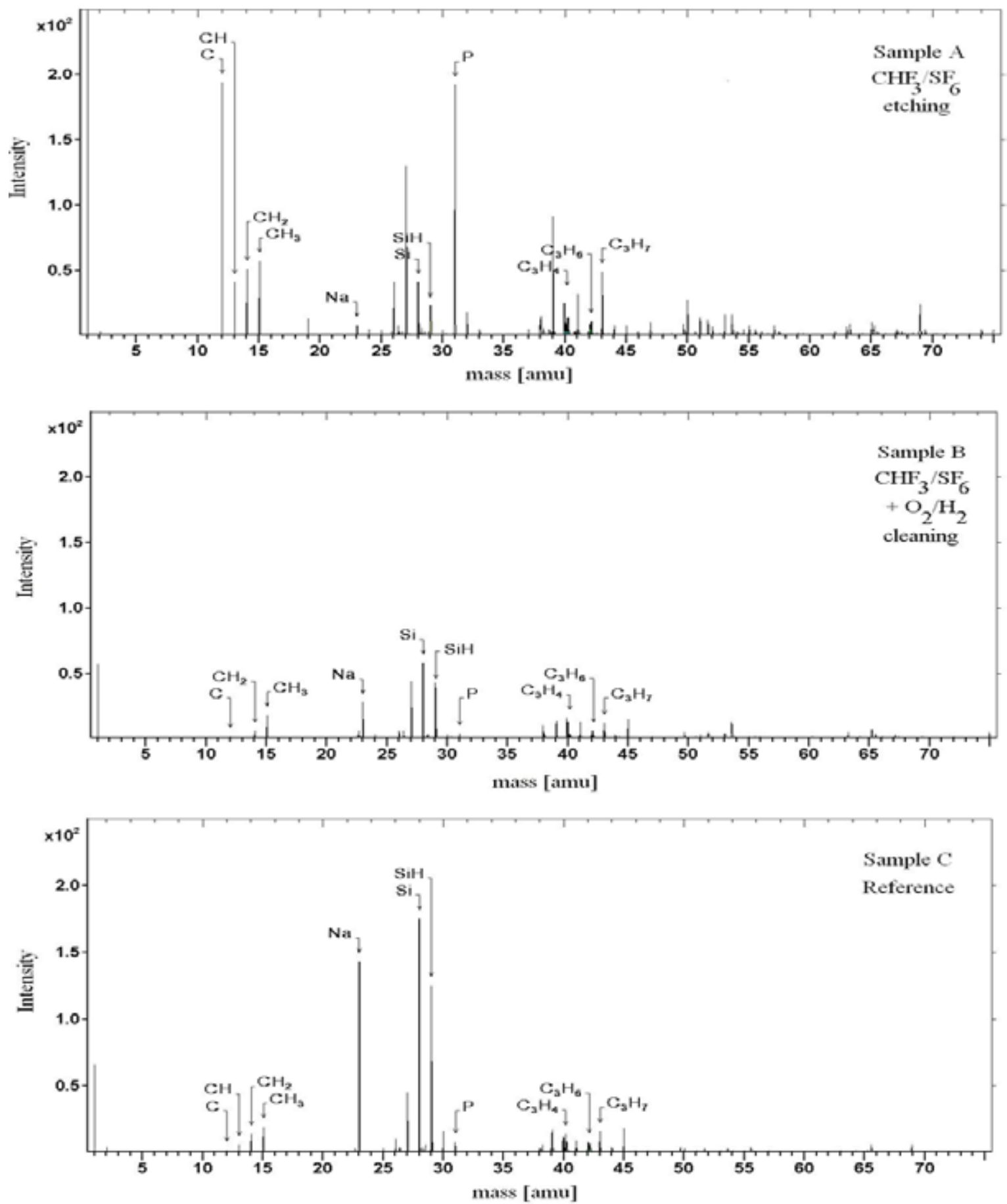

Figure (7). TOF-SIMS measurements; (a) Dry PSG etching with $\mathrm{CHF}_{3} / \mathrm{SF}_{6}$, sample A. (b) An extra $\mathrm{O}_{2} / \mathrm{H}_{2}$ dry plasma cleaning, sample B. (c) reference, PSG etched in HF, sample C.

From TOF-SIMS analysis, it is apparent that an extra $\mathrm{O}_{2} / \mathrm{H}_{2}$ cleaning step can improve the surface due to the polymer layer removal from the surface and the chemical contamination can be avoided or eliminated.
In order to evaluate the optimum plasma cleaning conditions necessary for best solar cell performance, the dependence of the solar cell characteristics on plasma operating conditions during $\mathrm{O}_{2} / \mathrm{H}_{2}$ dry 
cleaning is investigated. For this purpose, many plasma parameters, such as RF plasma power, reactor pressure, tube temperature, gas flow rate, etc. are considered. Open circuit voltage and therefore efficiency are the solar cell parameters significantly most affected by the etching process. Therefore, we describe only the dependence of these solar cell parameters on the different operating plasma conditions.

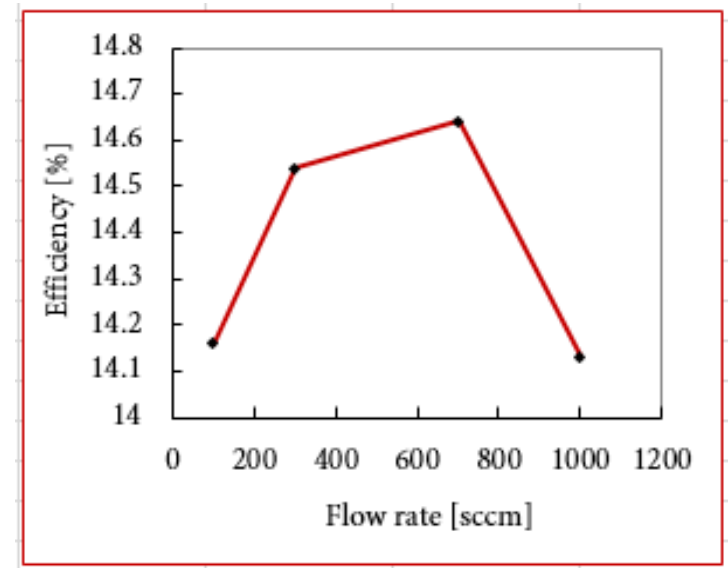

Figure (8). Effect of hydrogen flow rate on the efficiency of dry cleaned solar cell.

As illustrated in Figures 5 and 6 additional plasma cleaning of the wafer surface after dry PSG etching can improve the solar cell performance when both hydrogen and oxygen gases are used in one etching process $\left(\mathrm{O}_{2} / \mathrm{H}_{2}\right.$ clean $)$. The dependence of the efficiency and the open circuit voltage on the hydrogen flow rate is investigated, keeping the other plasma parameters constant. Figures 8 and 9 show that the efficiency and $\mathrm{V}_{\text {oc }}$ of the solar cell performance increase as the hydrogen flow rate is increasing due to the ability of the hydrogen gas to remove the polymer layer from the wafer surface yielding an enhancement in the cell performance. A hydrogen flow rate of more than $750 \mathrm{sccm}$ leads to a rapid decrease in $\mathrm{V}_{\mathrm{oc}}$ and efficiency because of an etch-back of the emitter. Therefore, it is not possible to use $\mathrm{H}_{2}$ flow rates greater than this value.

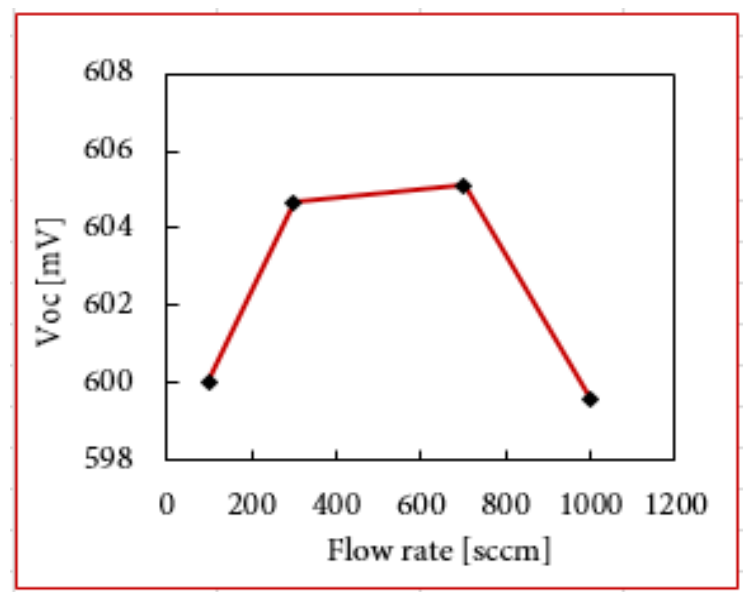

Figure (9). Effect of hydrogen flow rate on $V_{\text {oc }}$ of dry cleaned solar cell.

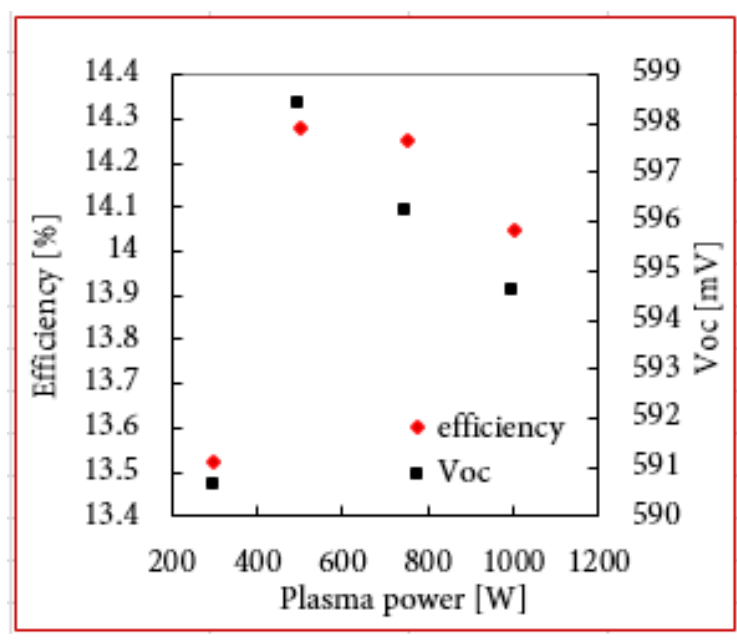

Figure (10). Effect of plasma power on $V_{o c}$ and efficiency at constant pressure and temperature.

Figure 10 shows the influence of the plasma power (300-1000 watt) on the $\mathrm{V}_{\mathrm{oc}}$ and cell efficiency. It is observed that the plasma power has a significant effect on the solar cell efficiency and open circuit voltage values. 
Both $\mathrm{V}_{\text {oc }}$ and efficiency are very low at low plasma power. As the power increases, the efficiency and $\mathrm{V}_{\text {oc }}$ are increasing until they reach to the maximum values at 500 watt. Any increase in the plasma power above this value leads to a drop in these solar cell parameters.

The effect of the tube temperature on solar cell parameters is also determined. The temperature is varied between 200 and $400{ }^{\circ} \mathrm{C}$. It is found that the temperature has a significant impact on the plasma cleaning process. From Figure 11, we notice that the increase in temperature from its low values leads to increasing efficiency while Voc is decreasing. As the temperature increases above $250{ }^{\circ} \mathrm{C}$, an increase in $\mathrm{V}_{\text {oc }}$ occurs. The solar cell efficiency and $V_{\text {oc }}$ reach their peak values at $350{ }^{\circ} \mathrm{C}$. A further increase in temperature causes a drop in both solar cell parameters. A reason for this may be due to the wafer surface damaging caused by high temperature processing.

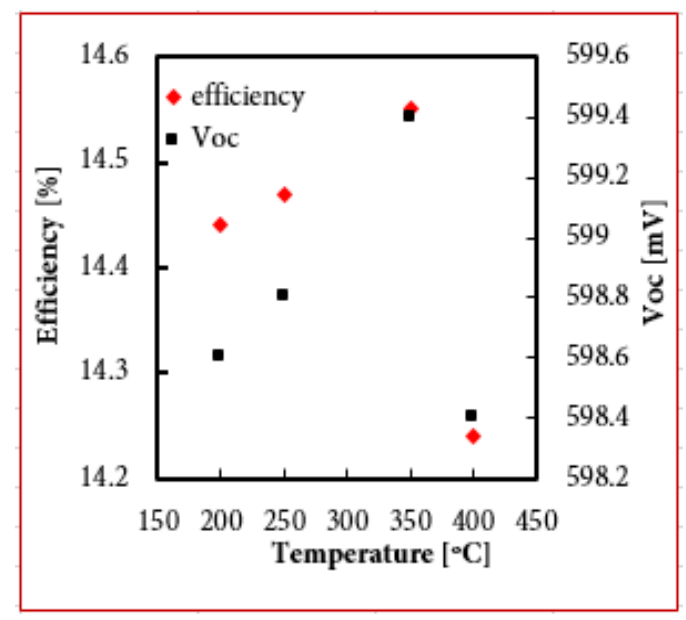

Figure (11). Effect of tube temperature on $\mathrm{V}_{\text {oc }}$ and efficiency of dry etched solar cell.

The influence of the hydrogen plasma cleaning time on the solar cell performance is analysed. The relationship between the plasma cleaning time and the efficiency and $\mathrm{V}_{\text {oc }}$ is illustrated in Figure 12. As can be seen, long etch times can improve both the open circuit voltage and cell efficiency. Further increase in etching time causes a high increase in tube temperature which leads to a degradation in the cell performance.

The measured parameters of the optimized dry processed solar cells and wet chemical processed ones are listed in Table 1. It is demonstrated that the solar cell characteristics are improved when an additional plasma $\mathrm{O}_{2} / \mathrm{H}_{2}$ cleaning treatment is implemented after dry PSG etching achieving a gain in cell efficiency of about $0.6 \%$ absolute compared to the cells without further cleaning treatment. On the other hand, the results have shown that the solar cell parameters for dry plasma cleaning process are better than the results that obtained after a dry PSG etching followed by an additional wet chemical cleaning step using the Piranha solution $\left(\mathrm{H}_{2} \mathrm{SO}_{4} / \mathrm{H}_{2} \mathrm{O}_{2}\right)$ [13].

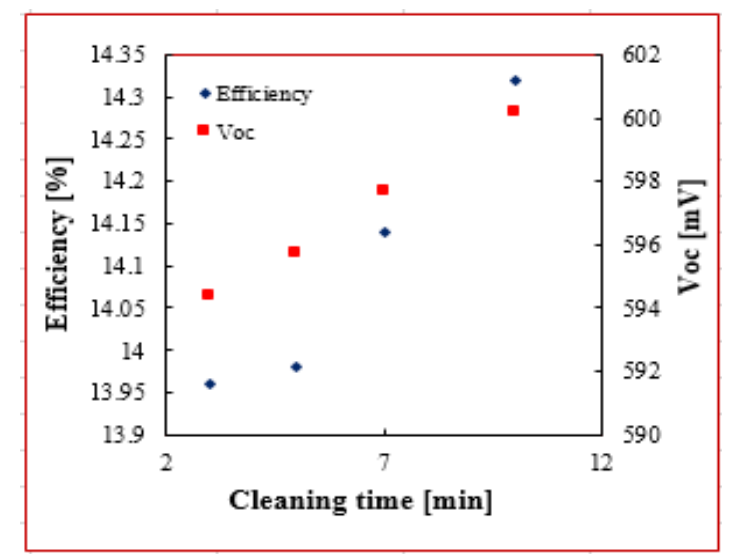

Figure (12). Effect of hydrogen plasma etching time on solar cell performance 
In comparison with the reference wet chemically etched cells, it is observed that most of the cell characteristics are comparable. However, we notice that $\mathrm{V}_{\text {oc }}$ of dry plasma cleaned cell is still low compared to the wet chemical cleaned cell and the wet chemical reference one. This can be attributed to still existing polymer residues due to the remaining damaging layer which can not be completely removed during the $\mathrm{O}_{2} / \mathrm{H}_{2}$ cleaning process.

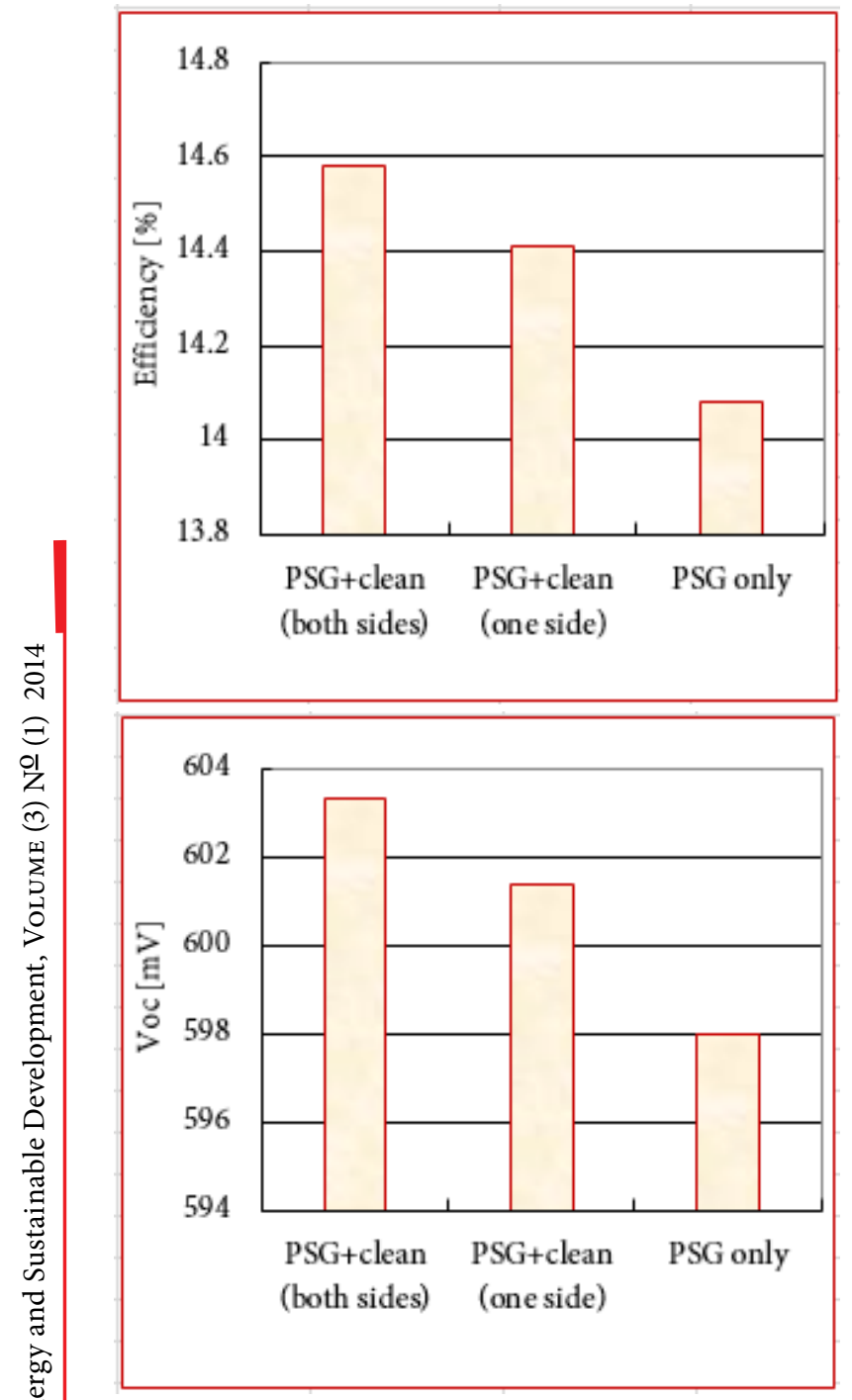

Figure (13). Measured open circuit voltage and the solar cell efficiency with different plasma cleaning steps.
In this work, we performed further investigation and development towards an evaluation of PSG etching and post cleaning of the front and rear wafer surfaces, respectively. In this case, we found that when a dry plasma etching is also applied on the back side of the wafer surface for PSG removal and extra post cleaning treatment, the solar cell performance is improved, as shown in Figure 13.

Table (1). I-V measurements (average values) of dry etched mc-Si solar cells compared to wet chemically processed cells.

\begin{tabular}{|c|c|c|c|c|}
\hline & $\begin{array}{c}\mathrm{J}_{\mathrm{sc}} \\
{[\mathrm{mA} /} \\
\left.\mathrm{cm}^{2}\right]\end{array}$ & $\begin{array}{c}\mathrm{V}_{\mathrm{oc}} \\
{[\mathrm{mV}]}\end{array}$ & $\begin{array}{l}\text { F.F } \\
{[\%]}\end{array}$ & $\begin{array}{c}\mathrm{h} \\
{[\%]}\end{array}$ \\
\hline $\begin{array}{l}\text { Only } \\
\text { dry PSG } \\
\text { etching }\end{array}$ & 30.2 & 594.3 & 77.8 & 14.0 \\
\hline $\begin{array}{l}\text { Dry PSG } \\
\text { etching } \\
\text { and } \mathrm{O}_{2} / \mathrm{H}_{2} \\
\text { plasma } \\
\text { cleaning }\end{array}$ & 31.1 & 599.4 & 78.0 & 14.6 \\
\hline $\begin{array}{l}\text { Dry PSG } \\
\text { etching } \\
\text { and wet } \\
\text { chemical } \\
\text { cleaning } \\
\mathrm{H}_{2} \mathrm{SO}_{4} / \\
\mathrm{H}_{2} \mathrm{O}_{2}\end{array}$ & 30.3 & 602.64 & 77.2 & 14.1 \\
\hline $\begin{array}{l}\text { Wet } \\
\text { chemical } \\
\text { reference } \\
\text { (HF dip) }\end{array}$ & 31.0 & 605.2 & 78.2 & 14.7 \\
\hline
\end{tabular}

As can be seen, both the open circuit voltage and the efficiency are improved after additional plasma cleaning for both 
wafer sides compared to one sided cleaning treatment. The lowest solar cell efficiency value is obtained when only PSG etching is applied without any extra surface cleaning.

\section{CONCLUSIONS}

Increasing of the solar cell efficiency, while maintaining a low production cost is the primary goal of the PV research groups. In this study, an effort has been undertaken towards the multi-crystalline silicon solar cells performance improvement.

A dry plasma etching technique for mcSi solar cell fabrication is implemented as an alternative to the wet chemical etching. A dry PSG etching process, as one application of plasma etching technology, is investigated and developed. By using $\mathrm{CHF}_{3} / \mathrm{SF}_{6}$ mixture gases in a commercial SiN-PECVD system, the PSG layer, which is formed during $\mathrm{POCl}_{3}$ diffusion, can be removed achieving high $\mathrm{SiO}_{2} / \mathrm{Si}$ selectivity ratio. The dependence of the solar cell characteristics on the plasma temperature variation is studied and optimized.

During the PSG removal, a thin polymer film is formed on the silicon wafer surface due to the carbon containing in the $\mathrm{CHF}_{3}$ gas. A dry plasma cleaning treatment for a polymer film deposited on the silicon wafer surface during PSG etching is developed. This polymer layer is removed by applying an additional post cleaning treatment using both oxygen and hydrogen as plasma etching gases with optimum plasma operating conditions. Due to this additional cleaning step, the hydrocarbon compounds formed on the Si wafer surface after PSG etching are eliminated. It is found that the solar cell performance can be improved by extra dry plasma cleaning after the PSG etching and prior to the SiN-PECVD deposition step. However, an efficiency gain of about $0.6 \%$ and $0.5 \%$ absolute is obtained compared to the cells with no further cleaning treatment and the cells with additional wet chemical cleaning process, respectively. On the other hand, the over all solar cell characteristics can reach values close to that achieved by the conventional wet chemical etching process.

\section{REFERENCES}

[1]. S. Narayanan, Solar Energy Materials \& Solar Cells 74 (2002) 107-115

[2]. R. Lüdemann, S. Schaefer, C. Schule, C. Hebling, Proceedings 26th IEEE PVSC, Anaheim, CA, USA, 1997, 159.

[3]. R. Lüdemann et. al, 2nd world conference and exhibition on photovoltaic solar energy conversion, Vienna, Austria, 6-10 July 1998.

[4]. V. Gazuz, K. Feldrapp, R. Auer, R. Brendel, M. Schulz, Solar Energy Materials \& Solar Cells 72 (2002) 277.

[5]. H.F.W. Dekkers, G. Agostinelli, D. Dehertoghe, G. Beaucarne, Proceedings 19th European Photovoltaic Solar Energy Conference, Paris (2004) 412.

[6]. A. Kagilik, W.A. Nositschka, O. Voigt, H. Kurz, Proceedings 19th European Photovoltaic Solar Energy Conference, (2004) 636.

[7]. L. Debarge, J. Boudaden, D. Ballutaud, R. Monna, J.C. Muller, Solar Energy Materials \& Solar Cells 72 (2002) 247.

[8]. J. Rentsch, F. Binaie, C. Schetter, H. Schlemm, K. Roth, D. Theirich, R. Preu, Proceedings 
19th European Photovoltaic Solar Energy

Conference, Paris (2004) 891.

[9]. W.A. Nositschka, O. Voigt, H. Kurz,

Proceedings 17th European Photovoltaic Solar Energy Conference, (2001) 1712.

[10]. W.A. Nositschka, A. Kenanoglu, O. Voigt,

D. Borchert, H. Kurz, Proceedings 3rd World Conference on Photovoltaic Energy Conversion, Osaka, Japan, 2003.

[11]. J. Rentsch, G. Emanuel, C. Schetter, T. Aumann, D. Theirich, J. Gentischer, K. Roth, M. Fritzsche, K.-H. Dittrich, R.
Preul, Proceedings 3rd World Conference on Photovoltaic Energy Conversion, Osaka, Japan, 2003.

[12]. A. Kagiliket. al., Proceedings 20th European Photovoltaic Solar Energy Conference, (2005) 1325.

[13]. G. Mannino, F. Priolo, V. Privitera, V. Raineri, C. Spinella, E. Napolitani, A. Carnera, G. Arena, A. Messina, C. Rapisarda, J. Appl. Phys., Vol. 84, No. 12, December 1998, 6628. 